\title{
REPORT ON THE 1997 ACTIVITY OF SHRUB MUD VOLCANO, WRANGELL-ST. ELIAS NATIONAL PARK AND PRESERVE, SOUTH CENTRAL ALASKA
}

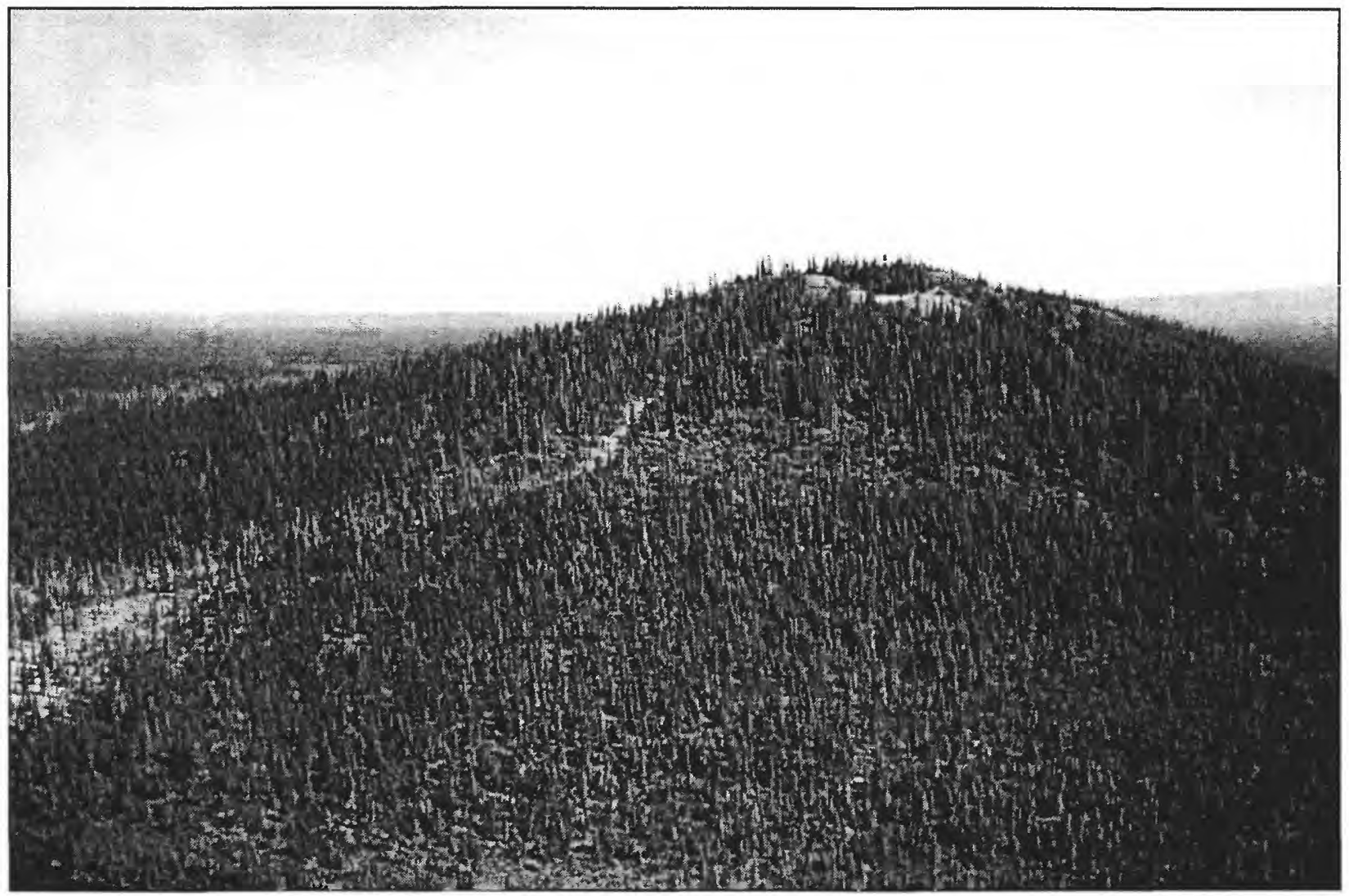

U.S. GEOLOGICAL SURVEY OPEN-FILE REPORT 98-128 


\title{
U.S. DEPARTMENT OF THE INTERIOR
}

\author{
U.S. GEOLOGICAL SURVEY
}

\section{REPORT ON THE 1997 ACTIVITY OF SHRUB MUD VOLCANO, WRANGELL-ST. ELIAS NATIONAL PARK AND PRESERVE, SOUTHCENTRAL ALASKA}

by

\author{
Donald H. Richter ${ }^{1}$, Robert B. Symonds ${ }^{2}$, Danny S. Rosenkrans ${ }^{3}$, \\ Robert G. McGimsey ${ }^{1}$, William C. Evans ${ }^{4}$, and Robert J. Poreda ${ }^{5}$
}

${ }^{1}$ U.S. Geological Survey, Alaska Volcano Observatory, 4200 University Drive, Anchorage, AK 99508

${ }^{2}$ U.S. Geological Survey, Cascades Volcano Observatory, 5400 MacArthur Blvd., Vancouver, WA 98661

${ }^{3}$ Wrangell-St Elias National Park and Preserve, P.O. Box 439, Copper Center, AK 99573

${ }^{4}$ U.S. Geological Survey, 345 Middlefield Road, Menlo Park, CA 94025

${ }^{5}$ Dept. of Earth and Environmental Science, 227 Hutchison Hall, University of Rochester, Rochester, NY 14627

\section{Open-file Report 98-128}

This report is preliminary and has not been reviewed for conformity with U.S. Geological Survey editorial standards or with the North American Stratigraphic Code. Any use of trade, product, or firm names is for descriptive purposes only and does not imply endorsement by the U.S.

Government. 
CONTENTS

\section{Page}

$\begin{array}{ll}\text { ABSTRACT } & 4\end{array}$

INTRODUCTION 4

GEOLOGIC SETTING AND HISTORICAL ACTIVITY 4

1997 ACTIVITY 5

GAS SAMPLING AND ANALYTICAL METHODS 6

$\begin{array}{ll}\text { ANALYTICAL RESULTS } & 7\end{array}$

$\begin{array}{ll}\text { CONCLUSIONS } & 7\end{array}$

$\begin{array}{lc}\text { REFERENCES } & 8\end{array}$

\section{TABLES}

TABLE 1. Chemical composition of gases from Shrub mud volcano

\section{FIGURES}

COVER PHOTO. Oblique aerial view of Shrub mud volcano from the southwest on 30 June 1997, showing mud stream descending flank from the gusher vents.

Figure 1. Index map of Glennallen, Alaska, showing location of the Klawasi group of mud volcanoes.

Figure 2. Sketch map of Shrub mud volcano showing vents and mud deposits as of 21 and 30 June 1997.

Figure 3. Sketch map of Shrub mud volcano showing vents and mud deposits as of 13 August 1997. 


\section{ABSTRACT}

Shrub mud volcano, one of three in the Klawasi group in the Copper River Basin, Alaska, was reported to be erupting warm mud and $\mathrm{CO}_{2}$-rich gas in the spring of 1997. Three on-site investigations of the renewed activity were made on 21 and 30 June and on 13 August 1997. The current activity is much more vigorous and the erupted products hotter (up to $46^{\circ} \mathrm{C}$ ) than has been observed previously at the Klawasi group of mud volcanoes. The mud and gas erupt from several circular depressions and fissure vents on the mud volcano. Activity ranges from quiet effusion of bubbling mud to violent discharge of mud and gas, which sends mud up to $10 \mathrm{~m}$ above the vents. The gas discharges contain over $98 \% \mathrm{CO}_{2}$ and minor to trace amounts of meteoric gases $\left(\mathrm{N}_{2}, \mathrm{O}_{2}, \mathrm{Ar}\right), \mathrm{CH}_{4}$, and $\mathrm{He}$. Carbon isotope data suggest that the $\mathrm{CO}_{2}$ comes from a mixture of magmatic $\mathrm{CO}_{2}$ and $\mathrm{CO}_{2}$ from contact metamorphism of underlying limestone. Isotopic data also confirm that $\mathrm{He}$ in these gases derives from magmatic and crustal sources. The $\mathrm{CO}_{2}$ in the discharged gases is killing animals, birds, and trees in the vicinity of the mud volcano and poses a life-threatening hazard to human visitors.

\section{INTRODUCTION}

Shrub mud volcano, in the Copper River Basin, approximately $27 \mathrm{~km}$ east of Glennallen, Alaska (Figures 1 and 2), began to vigorously erupt potentially dangerous $\mathrm{CO}_{2}$-rich gas and warm saline mud in the spring of 1997 . This activity may have begun, on a smaller scale, in 1996 according to prevously unreported observations. The 1997 activity was first noticed by Alaska Department of Fish and Game personnel on 12 June 1997. Since then, the activity has been monitored by the U.S. Geological Survey and the National Park Service. On site investigations were conducted on 21 and 30 June (Figure 3) and on 13 August 1997 (Figure 4), and an aerial inspection was made on 2 December 1997. During the investigation on 30 June 1997, we collected gases from one of the vents. Although the eruption poses no hazard to Glennallen or other communities in the Copper River Basin, the gas does pose a potential hazard for human visits to the mud volcano. This report describes our 1997 observations and also documents some preliminary analytical results on our gas samples.

\section{GEOLOGIC SETTING AND HISTORICAL ACTIVITY}

Shrub is one of three large mud volcanoes in the Copper River Basin near the west slope of Mt. Drum, a large Pleistocene volcano that was last active about 240,000 years ago (Richter and others, 1994). These mud volcanoes, called the Klawasi group, are elevated some 50-100 m above the surrounding terrain and are constructed entirely of material derived from the underlying glaciolacustrine deposits of the Basin (Figure 2). Shrub has apparently been virtually inactive for many years. Minor activity was observed in the mid-1950's, but since then the mud volcano was probably quiet until the summer of 1996 when vigorous activity was observed. The other 2 mud volcanoes of the group, Upper and Lower Klawasi mud volcanoes (Figure 1), have been active throughout this period and have provided temperature and chemical data on the mud and gas discharges (Nichols and Yehle, 1961; Grantz and others, 1962; Motyka and others, 1989). These investigations show that the Klawasi mud volcanoes erupt $20-25^{\circ} \mathrm{C}$ mud mixed with Ca-poor, $\mathrm{Na}-\mathrm{HCO}_{3}$-rich saline water and $\mathrm{CO}_{2}$-rich gas. Motyka and others (1989) suggest 
that the warm saline water is connate in origin and that the $\mathrm{CO}_{2}$ derives from degassing of deepseated magma and contact decarbonation of underlying Mesozoic limestone beds.

The first known description of Shrub and its activity was presented by Nichols and Yehle (1961) who visited the mud volcano in 1955 and 1956. In 1955 a vegetation-bare depression, about $35 \mathrm{~m}$ in diameter, was present on the southwest side of the cone about $10 \mathrm{~m}$ below the summit. The depression contained 7 small pools, $5-45 \mathrm{~cm}$ in diameter, from which issued minor mud and gas. By 1956, only 4 pools, $2-5 \mathrm{~cm}$ in diameter, remained and both mud and gas discharges were reduced. This depression was apparently located in the area now occupied by the very active gusher vents (Figures 3 and 4). In August 1991 a brief examination of the mud volcano by one of us (DSR) revealed no activity, nor was there indication of any recent activity.

No other descriptions of Shrub mud volcano or reports of activity are known until the summer of 1996 when a helicopter pilot observed an active mud spring low on the north flank of the cone (Figure 3) and probably activity from the summit area near the present fissure vent (Fritz Wohlwend, Trans-Alaska Helicopters, Inc., Personal communication 1997). This activity was never reported publicly, but fortuitously we flew with this pilot on our first visit to the mud volcano on 21 June 1997.

\section{ACTIVITY}

The present ongoing activity at Shrub is much more vigorous, and the temperatures higher, than what has been observed in the past at the nearby Klawasi mud volcanoes. During the visit of 21 June we examined all known sites where mud or gas was discharging as well as a vent area for the 1996 activity (Figure 3 ). The most active area was immediately below (southeast of) the cone's summit where a 65 -m-long east-trending fissure was discharging copious amounts of mud and gas at $43^{\circ} \mathrm{C}$. Recently dead spruce trees on the slopes below this fissure suggest the area was also the site of summit activity in 1996. Mud and gas production was also vigorous at a central vent, about $1 \mathrm{~m}$ in diameter, within a group of three vents, about $100 \mathrm{~m}$ west of the fissure vent. The two other vents in this latter group were less active.

Approximately a third of the way down from the summit on the north side of the cone, in dense alder-willow-birch growth, a 4- to 6-m-diameter pit, 1- to 2-m-deep, was filled with very active bubbling mud. Although the pit had not discharged mud, leaves of alder and birch downslope from the pit were browned to heights as much as $2 \mathrm{~m}$ above the ground surface suggesting that significant amounts of $\mathrm{CO}_{2}$-rich gas may have flowed out of the pit prior to our visit. We did observe a dense layer of condensate (probably water mixed with $\mathrm{CO}_{2}$ ) up to about a meter above the roiling mud surface. Northwest of this gas/mud pit and lower on the cone's flank a number of small vents were quietly discharging mud, with no apparent gas, through a thick surficial organic mat. Mud discharging from the largest of these vents had a temperature of $47^{\circ} \mathrm{C}$, the hottest recorded on the mud volcano.

On 30 June we revisited Shrub to sample gases from the west end of the summit fissure. The fissure was still active but activity was restricted to a deep (about 3-5 $\mathrm{m}$ ) pit in the middle of the fissure; temperatures remained at $43^{\circ} \mathrm{C}$. The northernmost of the gushing vents was very active, noisily producing large bubbles of mud as much as $2 \mathrm{~m}$ in diameter that burst as high as $10 \mathrm{~m}$ above the vent. There was minor mud emission from the central vent and the southernmost vent was inactive. The mud/gas pit on the north flank was not visited, but we could see from the air that it was still active. 
A month and a half later on 13 August numerous changes in activity were observed, although vigorous mud and gas emission continued (Figure 4). The fissure vent was virtually inactive. In the deeper parts of the fissure some roily mud was present but none was reaching the surface. About $50 \mathrm{~m}$ south of the fissure a small pit (vent) was discharging a thin trickle of mud. At the gushing vents the former weakly active vent was now the major producer of mud and gas. The temperature was $46^{\circ} \mathrm{C}, \sim 3^{\circ} \mathrm{C}$ higher than measured on $21 \mathrm{June}$, and it was estimated that mud production was on the order of a cubic meter a minute. The formerly very active vent to the north was discharging some mud and a fourth - probably new-vent a few meters farther to the north was also active. The mud/gas pit lower on the north flank was also inactive, but about 10 $\mathrm{m}$ upslope from the pit was a new 3-m-wide collapse pit, at least $5 \mathrm{~m}$ deep, which appeared to have active mud at the bottom. At the mud vents lower down the flank of the cone it appeared that mud emission had decreased, but there were so many small vents, all hidden in the dense vegetation, that it was difficult to tell where and how much mud was being discharged. Between the 30 June and 13 August site visits there had been significant mud production from these lower vents as indicated by the covering of additional 1996 mud during this time frame. A temperature of $44^{\circ} \mathrm{C}$ was slightly lower than what was measured on 30 June.

A low-level flight over the mud volcano on 2 December 1997 revealed that activity continued at about the same level as observed in August. At the original mud /gas pit on the north flank of the cone, which was quiet on August 13, a small stream of mud was observed issuing from the pit and running down the cone. At the gusher vents it appeared a depression was forming, maybe similar to the basinal feature observed by Nichols and Yehle (1961) in 1955-56.

\section{GAS SAMPLING AND ANALYTICAL METHODS}

Gas samples were collected from the west end of the summit fissure on 30 June following the procedures of Fahlquist and Janik (1992). A 15-cm funnel was held over the surface of the bubbling mud. This funnel was attached to a short-length of Tygon tubing that led to an evacuated double-port sampling bottle. After purging air from the sampling line with a hand pump attached to the outlet port, we clamped the outlet and opened the bottle's inlet valve. At this site we filled one evacuated flask for analysis of bulk-gas composition and $\delta^{13} \mathrm{C}_{\text {in }} \mathrm{CO}_{2}$, and an additional flask for determining rare-gas isotopes. The rare-gas isotope flask was made of Corning-1720 glass and fitted with a high-vacuum stopcock to prevent leakage of He. We also collected two evacuated bottles partly filled with a known volume of $4 \mathrm{~N} \mathrm{NaOH}$ solution for additional determination of the bulk gas composition. These $\mathrm{NaOH}$-collected samples allow lower detection limits on some of the less abundant species (e.g., $\mathrm{H}_{2}$ and $\mathrm{CO}$ ) and are currently awaiting analysis by the U.S. Geological Survey (Menlo Park, CA).

One of the $\mathrm{NaOH}$-free evacuated-bottle samples was analyzed using gas chromatograph for $\mathrm{CO}_{2}, \mathrm{~N}_{2}, \mathrm{O}_{2}, \mathrm{CH}_{4}, \mathrm{Ar}, \mathrm{He}, \mathrm{H}_{2} \mathrm{~S}, \mathrm{H}_{2}, \mathrm{C}_{2} \mathrm{H}_{6}$, and $\mathrm{CO}$. This sample was also analyzed for $\delta^{13} \mathrm{C}$ in $\mathrm{CO}_{2}$ using a Finnigan MAT 251 after the sample was purified using liquid nitrogen traps on a high-vacuum line.

The helium isotope sample was analyzed using methods described elsewhere (Poreda and others, 1992; Poreda and Farley, 1992). The gases in the flasks were extracted on a high vacuum line constructed of stainless steel and Corning- 1724 glass. After removal of $\mathrm{H}_{2} \mathrm{O}$ vapor and $\mathrm{CO}_{2}$ 
at $-90^{\circ} \mathrm{C}$ and $-195^{\circ} \mathrm{C}$, respectively, the non-condensable gases $\left(\mathrm{He}, \mathrm{Ne}, \mathrm{Ar}, \mathrm{N}_{2}, \mathrm{CH}_{4}\right)$ were concentrated using a Toepler pump in series with a Hg-diffusion pump. The amount of noncondensable gas was measured using a calibrated gas splitter fitted with a capacitance manometer. Gas ratios $\left(\mathrm{N}_{2}, \mathrm{Ar}, \mathrm{CH}_{4}\right)$ were analyzed on a Dycor Quadrupole mass spectrometer fitted with a variable leak valve. The results are combined with the capacitance manometer measurement to obtain gas concentrations. Prior to isotope analyses, $\mathrm{N}_{2}$ and $\mathrm{O}_{2}$ were removed by reaction with $\mathrm{Zr}-\mathrm{Al}$ alloy (SAES-ST707), and Ar and Ne were adsorbed on activated charcoal at $77 \mathrm{~K}$ and at $40 \mathrm{~K}$, respectively. Helium isotope ratios and concentrations were then analyzed on a VG 5400 Rare Gas Mass Spectrometer fitted with a Faraday cup and a Johnston electron multiplier. The Mass Spectrometer was also used to measure concentrations of argon, neon, and krypton isotopes. The $2 \sigma$ errors in the ${ }^{3} \mathrm{He} /{ }^{4} \mathrm{He}$ ratios are $\pm 0.3 \%$ for the reported helium isotope value.

\section{ANALYTICAL RESULTS}

Table 1 shows the chemical and isotopic analyses of the two evacuated-bottle samples collected on 30 June 1997 . The chemical analysis is reported (in mol\%) as a dry gas composition. The results show the sample contains over $98 \% \mathrm{CO}_{2}$ with minor to trace amounts of $\mathrm{N}_{2}, \mathrm{O}_{2}, \mathrm{CH}_{4}, \mathrm{Ar}$, and $\mathrm{He} . \mathrm{H}_{2}, \mathrm{C}_{2} \mathrm{H}_{6}, \mathrm{H}_{2} \mathrm{~S}$, and $\mathrm{CO}$ are below detection. The amount of $\mathrm{H}_{2} \mathrm{O}$ in the sample is necessarily small because the vapor pressure of water at sea level is only $0.018 \mathrm{~atm}$ for the collection temperature of $16^{\circ} \mathrm{C}$.

Ratios of $\mathrm{N}_{2} / \mathrm{Ar}(58.0)$ and $\mathrm{N}_{2} /\left(\mathrm{O}_{2}+\mathrm{Ar}\right)(2.02)$ are close to the mixing line between air $\left(\mathrm{N}_{2} / \mathrm{Ar}=83.6, \mathrm{~N}_{2} /\left(\mathrm{O}_{2}+\mathrm{Ar}\right)=3.57\right)$ and air-saturated water $\left(\mathrm{N}_{2} / \mathrm{Ar}=38.3, \mathrm{~N}_{2} /\left(\mathrm{O}_{2}+\mathrm{Ar}\right)=1.78\right)$. This suggests that $\mathrm{N}_{2}, \mathrm{O}_{2}$, and $\mathrm{Ar}$ in this sample come from a meteoric source. After removing these shallow meteoric components and discounting any unanalyzed $\mathrm{H}_{2} \mathrm{O}$, the renormalized composition contains $99.97 \% \mathrm{CO}_{2}, 0.0313 \% \mathrm{CH}_{4}$, and $0.0004 \% \mathrm{He}$, which we take as the gas composition from depth.

The bulk gas composition of the 1997 Shrub gases (Table 1) is very similar to past analyses from Upper and Lower Klawasi mud volcanoes (e.g., up to $99 \% \mathrm{CO}_{2}$; Reitsema, 1979; Motyka and others, 1989), suggesting the 1997 Shrub mud volcano gases come from the same origin. This is confirmed by the $\delta^{13} \mathrm{C}$ in $\mathrm{CO}_{2}$ and ${ }^{3} \mathrm{He} /{ }^{4} \mathrm{He}$ data (Table 1), which lie within the range of previous analyses of the Upper and Lower Klawasi gases $\left(\delta^{13} \mathrm{C}\right.$ in $\mathrm{CO}_{2}=-4.1$ to $-8.1 \%$, ${ }^{3} \mathrm{He} /{ }^{4} \mathrm{He}=2.6$ - 4.1 $\mathrm{R}_{d} / \mathrm{R}_{\mathrm{a}}$; Reitsema, 1979 ; Motyka and others, 1989). The $\delta^{13} \mathrm{C}$ in $\mathrm{CO}_{2}$ data supports the interpretation of Motyka and others (1989) that $\mathrm{CO}_{2}$ from the Klawasi group of mud volcanoes is a mixture of magmatic $\mathrm{CO}_{2}\left(\delta^{13} \mathrm{C}=-5\right.$ to $-8 \%$; Allard, 1983) and $\mathrm{CO}_{2}$ derived from contact metamorphism of local carbonates $\left(\delta^{13} \mathrm{C}=+2.3-+2.9 \%\right.$ for Chitistone Limestone; Reitsema, 1979). As suggested by Motyka and others (1989), the ${ }^{3} \mathrm{He} /{ }^{4} \mathrm{He}$ data suggest that $\mathrm{He}$ derives from a mixture of mantle $\left(8 \mathrm{R}_{\mathrm{a}}\right)$ and crustal $\left(0.02 \mathrm{R}_{\mathrm{a}}\right)$ sources.

\section{CONCLUSIONS}

Although the renewed activity at Shrub mud volcano is not considered to be a precursor to a magmatic volcanic eruption, the discharge of copious amounts of $\mathrm{CO}_{2}$ does present a local life-threatening hazard. Numerous dead snowshoe hares and song birds have been observed near 
the gas-emitting collapse pits, and more birds and animals are undoubtedly now buried by mud at other vents. $\mathrm{CO}_{2}$ is an odorless and colorless gas that does pose a serious hazard to humans. Breathing air with $\geq 30 \% \mathrm{CO}_{2}$ causes rapid unconsciousness and, if sustained for several minutes, death in humans (Stupfel and Le Guern, 1989). Normally $\mathrm{CO}_{2}$ dissipates rapidly when discharged into the atmosphere. But the occasional presence of dead animals and birds, and brown vegetation around some of Shrub's vents demonstrates that concentrated streams of $\mathrm{CO}_{2}$ are occasionally discharged from Shrub. These $\mathrm{CO}_{2}$ streams would obviously be very dangerous or fatal to humans, because they can discharge without warning and are invisible. Another hazard for humans exists when $\mathrm{CO}_{2}$, which is heavier than air, concentrates in depressions, snow, or manmade structures. Entering natural depressions, digging snow pits, or tent camping on or near Shrub could be dangerous. Thus, we discourage visits to the mud volcano while it is in this potentially dangerous, active phase. The U.S. Geological Survey and the National Park Service will continue to monitor the activity.

\section{REFERENCES}

Allard, P., 1983, The origin of hydrogen, carbon, sulfur, nitrogen, and rare gases in volcanic exhalations: evidence from isotope geochemistry, in Tazieff, H., and Sabroux, J. C., eds., Forecasting Volcanic Events: Amsterdam, Elsevier, p. 337-386.

Fahlquist, L., and Janik, C. J., 1992, Procedures for collecting and analyzing gas samples from geothermal systems: U.S. Geological Survey Open-File Report 92-211, 19 p.

Grantz, Arthur, White, D.E., Whitehead, H.C., and Tagg, A.R., 1962, Saline springs, Copper River Lowland, Alaska: American Association of Petroleum Geologists Bull. v. 46, no. 11, p.1990-2002.

Motyka, R.J., Poreda, R.J., and Jeffrey, A.W.A., 1989, Geochemistry, isotopic composition, and origin of fluids emanating from mud volcanoes in the Copper River basin, Alaska:

Geochimica et Cosmochimica Acta, v. 53, p. 29-41.

Nichols, D.R. and Yehle, L.A., 1961, Mud volcanoes in the Copper River Basin, Alaska, in Raasch, G.O., ed., Geology of the Arctic: International Symposium on Arctic Geology, 1st, Calgary, 1960, Proceedings, v. 2, p. 1063-1087.

Poreda, R. J., and Farley, K. A., 1992, Rare gases in Samoan xenoliths: Earth and Planetary Science Letters, v. 113, p. 129-144.

Poreda, R. J., Craig, H., Arnorsson, S., and Welhan, J. A., 1992, Helium isotopes in Icelandic geothermal systems: I. ${ }^{3} \mathrm{He}$, gas chemistry, and ${ }^{13} \mathrm{C}$ relations: Geochimica et Cosmochimica Acta, v. 56, p. 4221-4228. 
Reitsema, R. H., 1979, Gases of mud volcanoes in the Copper River Basin, Alaska. Geochimica et Cosmochimica Acta, v. 43, p. 183-187.

Richter, D.H., Moll-Stalcup, E.J., Miller, T.P., Lanphere, M.A., Dalrymple, G.B., and Smith, R.L., 1994, Eruptive history and petrology of Mount Drum volcano, Wrangell Mountains, Alaska: Bulletin of Volcanology, v. 56, p.29-46.

Stupfel, M., and Le Guern, F., 1989, Are there biomedical criteria to assess an acute carbon dioxide intoxication by a volcanic emission?: Journal of Volcanology and Geothermal Research, v. 39, p. 247-264. 
Table 1 - Chemical compositions

of gases from Shrub mud volcano.

\begin{tabular}{|c|c|}
\hline $\begin{array}{l}\text { Field numbers: } \\
\text { Location: }\end{array}$ & $\begin{array}{l}\quad 970630-2 \\
\text { west end of Fissure } \\
\text { vent }\end{array}$ \\
\hline Date: & June 30, 1997 \\
\hline $\mathrm{T}^{\circ} \mathrm{C}$ & 16 \\
\hline \multicolumn{2}{|c|}{ Chemical Species of Dry Gas (mol\%) } \\
\hline $\mathrm{CO}_{2}$ & 98.3546 \\
\hline $\mathrm{N}_{2}$ & 1.0613 \\
\hline $\mathrm{O}_{2}$ & 0.5069 \\
\hline $\mathrm{CH}_{4}$ & 0.0308 \\
\hline $\mathrm{Ar}$ & 0.0183 \\
\hline $\mathrm{He}$ & 0.0004 \\
\hline $\mathrm{CO}$ & $<0.001$ \\
\hline $\mathrm{H}_{2} \mathrm{~S}$ & $<0.0005$ \\
\hline $\mathrm{H}_{2}$ & $<0.0002$ \\
\hline $\mathrm{C}_{2} \mathrm{H}_{6}$ & $<0.0002$ \\
\hline \multicolumn{2}{|c|}{ Selected ratios } \\
\hline $\mathrm{N}_{2} / \mathrm{Ar}$ & 58.0 \\
\hline $\mathrm{N}_{2} /\left(\mathrm{O}_{2}+\mathrm{Ar}\right)$ & 2.02 \\
\hline \multicolumn{2}{|c|}{ Isotopic Composition } \\
\hline $8^{13} \mathrm{C}_{\text {in }} \mathrm{CO}_{2}\left(\%_{00} \mathrm{PBD}\right)$ & -4.64 \\
\hline${ }^{3} \mathrm{He} e^{\mu} \mathrm{He}\left(\mathrm{R}_{d} \mathrm{R}_{\mathbb{q}}\right)^{\dagger}$ & 3.54 \\
\hline
\end{tabular}




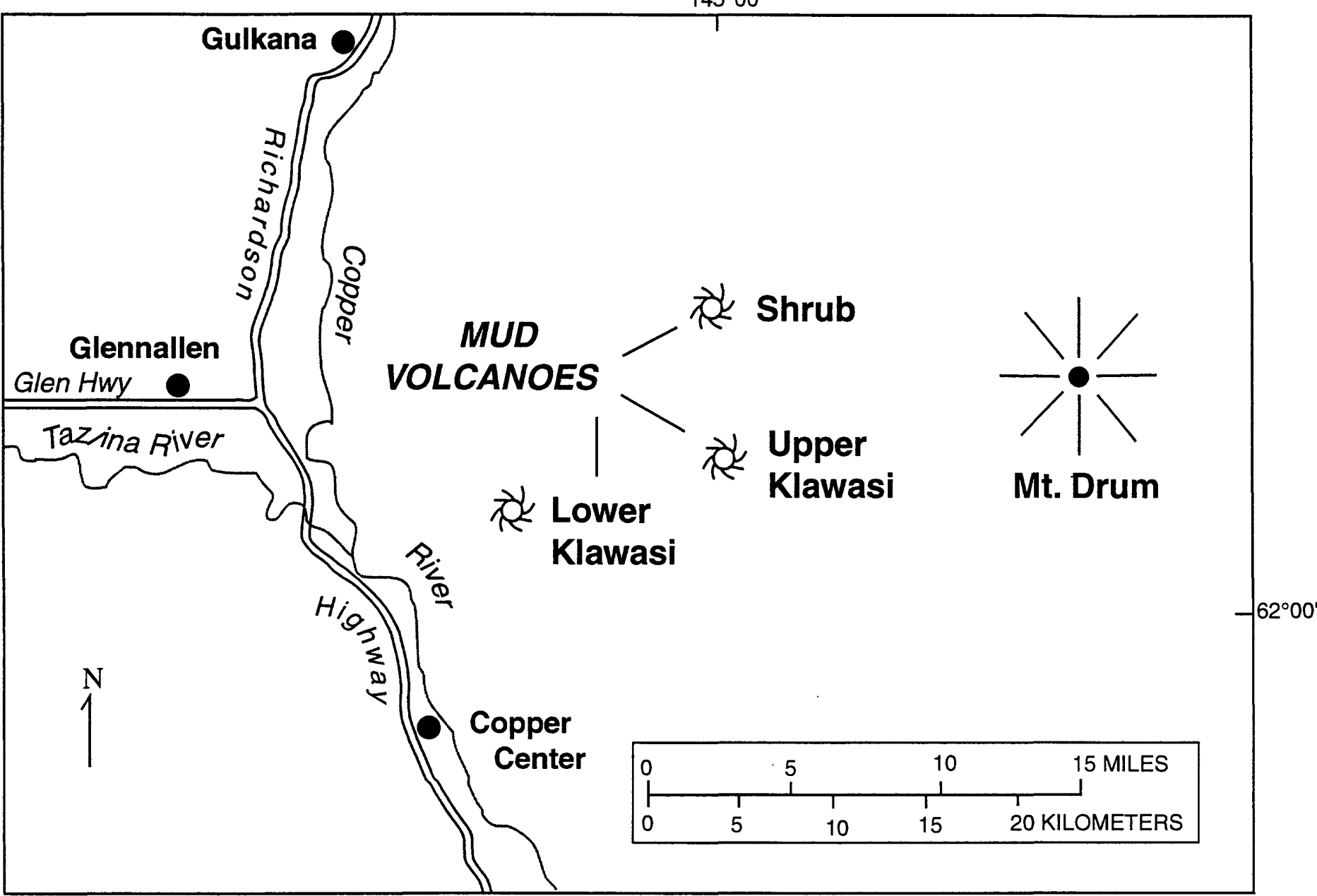

Figure 1. Index map of the Glennallen, Alaska area showing location of Shrub and Klawasi mud volcanoes. 


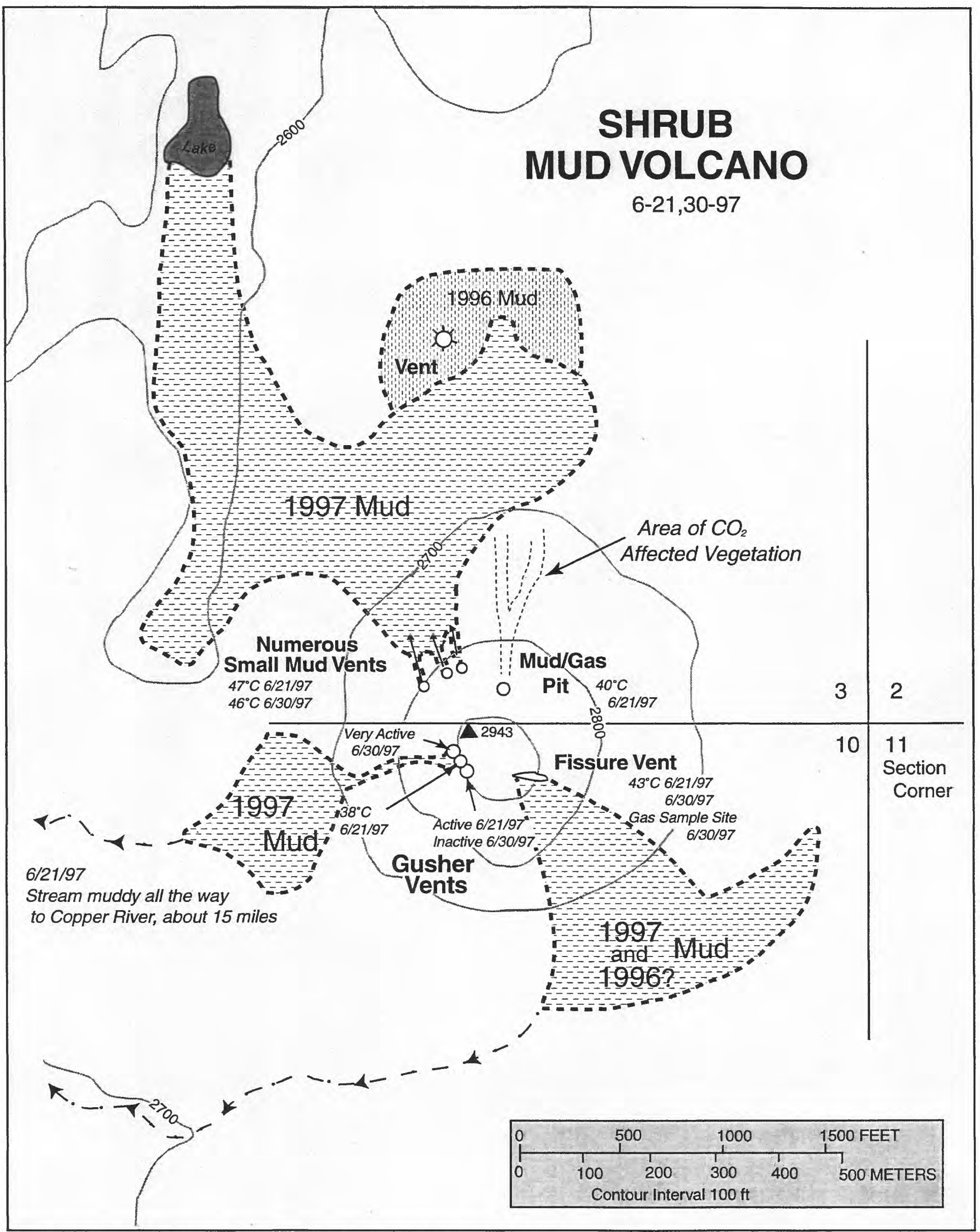

Base from U.S. Geological Survey Gulkana A-3 Quadrangle, Alaska. Graphics by K.Wallace

Figure 3. Sketch map of Shrub mud volcano showing vents and extent of mud deposits as of June 21 and 30, 1997. 


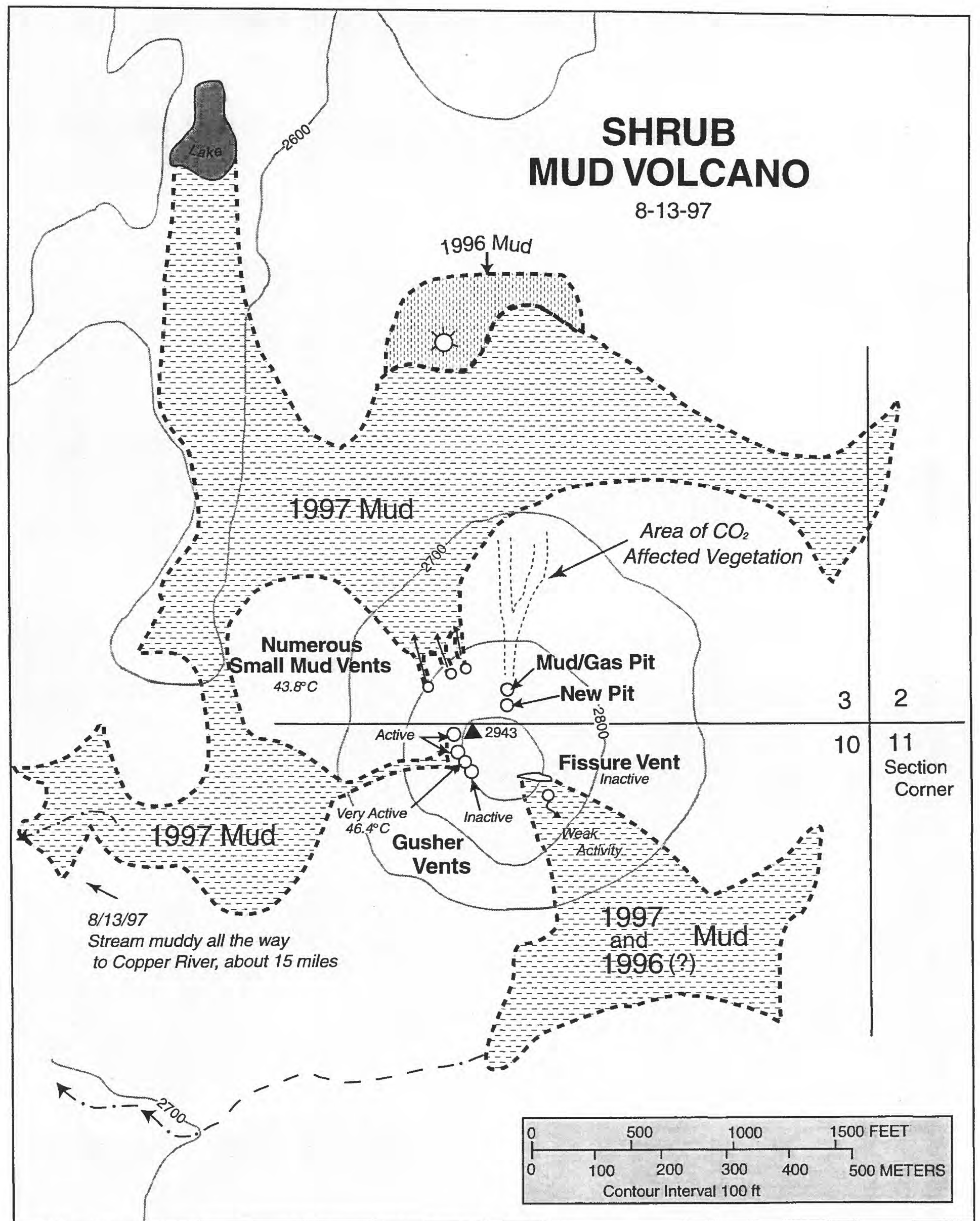

Base from U.S. Geological Survey Gulkana A-3 Quadrangle, Alaska. Graphics by K. Wallace

Figure 4. Sketch map of Shrub mud volcano showing vents and extent of mud deposits as of August 13, 1997. 